\title{
The programme of the nationalist action party: an iron hand in a velvet glove?
}

\section{E. Burak Arikan}

To cite this article: E. Burak Arikan (1998) The programme of the nationalist action party: an iron hand in a velvet glove?, Middle Eastern Studies, 34:4, 120-134, DOI: 10.1080/00263209808701246

To link to this article: https://doi.org/10.1080/00263209808701246

册 Published online: 06 Dec 2006.

Submit your article to this journal 지

Џ Article views: 215

4 Citing articles: 7 View citing articles 진 


\title{
The Programme of the Nationalist Action Party: An Iron Hand in a Velvet Glove?
}

\author{
E. BURAK ARIKAN
}

The death of Alparslan Türkes (1917-1997) brought to the surface rivalries within the Ülkücü Camia (Idealist Community)' which in the early 1990s had led to the division of the party into two separate political bodies. ${ }^{2}$ Today, the competition between the more Islamist and grass-root Idealists is expected to intensify, since Milliyetçi Hareket Partisi (MHP) faces a leadership crisis following the death of their Basbug. ${ }^{3}$ In their first party congress without the presence of their supreme leader, on 18-19 May 1997, the rivalries within the party surfaced and eight candidates, including the son of Türkeş, ran for the leadership of the party. Following the first round of the elections, six candidates decided to support Devlet Bahçeli, who had been trailing Tuğrul Türkeş. This decision was a turning point in the congress. At around 4.00 a.m. Türkeş, realizing that his chances of victory were minimal, organized a putsch and with the support of militant Idealists seized the congress administration chair. The scenes that followed resembled a gangster film. Fights broke out in the congress hall and even gunshots were heard. Consequently, the congress was suspended by the party administration. The scene seriously damaged the functioning of democracy in Turkey, and MHP lost its chance to present itself to the electorate as a respectable and democratic force. Before the congress, many commentators had been expecting the leadership election to enable MHP to reappraise itself and to find a legitimate place in Turkish politics by accepting democratic procedures, as some extreme right-wing parties have done elsewhere in Europe. However, the high hopes raised before the congress disappeared in the dark corridors of militant terrorism.

The anti-democratic incidents that dominated the congress did not surprise many academics, politicians and press members. MHP's name in Turkish politics has long been associated with the pre-1980 political turbulence, during which nearly 5,000 people were killed and around 20,000 wounded. Before the 1980 coup, the Idealists openly declared war against the Communists, and with their strong pro-state and antiCommunist stance believed that for the great cause (the preservation and 
continuity of the Turkish Republic) even armed struggle was legitimate. ${ }^{4}$ The basis of MHP's programme is Turkish nationalism, that is, in its narrowest definition: 'The love of Turkish nation, and loyalty and service to the Turkish state.' ${ }^{\prime}$ However, the limits of this service were rather obscurely interpreted by the Idealist cadres and as one recent development has shown, many MHP supporters were manipulated by the state in pursuing criminal activities. The latest scandal, which surfaced after a traffic accident, proved the illegal links between the state and the Idealists. ${ }^{6} \mathrm{~A}$ member of Parliament, Sedat Bucak, a police chief, Hüseyin Kocadağ and an Idealist, Abdullah Çatlı (or at least he himself claimed to be one), ${ }^{7}$ on Interpol's wanted list for international drug trafficking, were in a car involved in an accident in Susurluk province. The accident raised doubts in the minds of citizens as to whether the country was run by the state or by gangs. It was then that people better understood the words of one Idealist writer. In his book Ülkücüye Mektuplar [Letters to the Idealists] Adnan Büyükbas examines the psychology of the Idealist, claiming that Idealists are always ready to be shot for their native country, which nurtured them. ${ }^{8}$

TABLE 1

THE RESULTS OF MHP PARTICIPATION IN TURKISH ELECTIONS

\begin{tabular}{llcc}
\hline & Elections & Votes cast in \% & Number of MPs \\
\hline & & & \\
CKMP & 1965 & 2.2 & 11 \\
MHP & 1969 & 3.3 & 1 \\
MHP & 1973 & 3.4 & 3 \\
MHP & 1977 & 6.4 & 16 \\
MÇP & 1987 & 2.9 & - \\
MÇP & $1989^{*}$ & 4.1 & - \\
MÇP-RP & 1991 & 16.9 & 19 (RP 43) \\
MHP & $1994^{*}$ & 8 & - \\
MHP & 1995 & 8.6 & - \\
\hline
\end{tabular}

* Local elections

As this latest incident has shown, for the Idealists and the MHP it is the preservation of the native country that takes priority over all other issues. Any tactic, legal or illegal, is legitimate for achieving this sacred mission.

MHP ideology is predicated on a defensive reflex based on the existence of an enemy, fictitious or real, which has to be challenged and destroyed." During the 1960s the enemy was the Demokrat Parti (Democrat Party, DP) government, ${ }^{12}$ in the 1970 s it was Communism, in the 1980 s it was the 
Partia Karkaren Kürdistan (Kurdistan Worker's Party, PKK), and today it is the pro-Islamist Refah Partisi (Welfare Party, RP). ${ }^{13}$ By creating an enemy, the party on the one hand aims to unite elements of the extreme right in Turkey, and on the other seeks to find itself a legitimate place in the Turkish political spectrum. Accordingly, the most broadly held view of the MHP programme is that it is a single-issue party, the product of a defensive obsession with the preservation of the Turkish state. However, this fails to explain the presence of the MHP in Turkish politics for more than four decades, and the fact that it enjoys the support of ten per cent of the electorate.

The party programme is broadly influenced by the writings of a rightwing think-tank, known as Aydınlar Ocağı (Hearth of Intellectuals, AO), similar to the Nouvelle Droite in France. The programme in essence points towards a Fascist ideology which is subsumed by Turkish nationalism. Considering Fascism's narrowest definition, the MHP is anti-egalitarian, extreme nationalist, opposed to both liberalism and Communism, accepts the use of violence (although this is not in its programme, it is a historical fact that even party officials do not deny), and defends discrimination. The party claims to be supporting parliamentary democracy but the latest congress shows how it can easily push aside democratic means. On economic matters the party favours a protectionist model, based on import substitution. It advocates a mixed economic structure in which the state would control the strategic economic enterprises. ${ }^{14}$ Industry would be encouraged to use only Turkish resources. ${ }^{15}$ It is obvious that in the postGATT world (which enforces free trade measures in the world) the economic programme of the party fails to offer any alternatives that would integrate the Turkish economy into the world markets.

The purpose of this essay is to clarify the programme of the MHP and to see whether the party is disguising a Fascist doctrine as a nationalist conservative programme based on the acceptance of the primary principles of the Turkish Republic. Firstly, the development of the MHP programme will be emphasized, paying special attention to the Aydınlar Ocağı, given its influence on right-wing politics in Turkey in general and on extreme rightwing ideas in particular. The efforts of Aydınlar Ocağl, to present a legitimate façade for extreme nationalist and racist ideas are extremely important if the MHP is to establish its own version of Turkish nationalism. The ideas that are covered in the programme will be explored in the next section with reference to three main areas: Turkish nationalism, the economy, and the family. The MHP programme is a good example of how such movements can prepare a democratic programme while in fact combining Fascist elements with militant terrorism. 
The early foundations of the MHP programme date back to the late 1940s. In 1948, the first extreme right-wing party, Cumhuriyetçi Koylü Millet Partisi (Republican Farmers Nation Party, CKMP), was founded by the coalition of small proto-Fascist parties and movements. It was led by Marshal Fevzi Çakmak, who at the time was the symbol of extreme nationalistic ideas in Turkey. During the 1950 s, under the leadership of Osman Bolükbaşı, the party acquired a populist, conservative and nationalist stance, primarily supported by peasants and middle classes. In 1965, Alparslan Türkes and his friends were elected to the party chair. The first party programme, valid until the 1960s contained a corporatist, developmental-modernist ideology primarily underlined by a Kemalist restoration agenda. Between 1965-69, Turkist and virulent anti-Communist features started to acquire importance in party rhetoric. During the period the party was in close contact with Fascist organizations, such as Türkiye Milliyetçiler Birliği (Turkish Nationalists Union), ${ }^{16}$ Aydınlar Klübü (Intellectuals Club), and Vatansever Türk Teşkilatı (Native-Country Lovers Turkish Organization). These organizations, together with Komünizmle Mücadele Dernekleri ('Struggle Against Communism' Clubs) served an important role in the re-organization of the party and its ideology. In the 1967 congress of the party, a new programme was accepted, the main principle being 'communitarian nationalism' represented by the Dokuz Iş1k Doktrini (Nine Lights Doctrine, DID). Türkeş was declared Basbuğ, and he made his famous declaration: 'whoever joins the cause and becomes a traitor, kill him'.

Until the end of the 1960s the MHP supported the secular forces in the country. However, during the 1970s Türkeş and the MHP speakers defined Islam as an indispensable part of Turkish culture. Türkeş formulated this new combination as follows: 'We are as Turk as the Tengri mountain [it is in Central Asia where MHP believes Turk's ancestors migrated from] as Muslim as the Hira mountain [which is located in the holylands for Muslims in Saudi Arabia]. Both philosophies are our principles. ${ }^{17}$ This change in the party programme in fact was tactical and instrumental. It was instrumental since Islam was interpreted as an ideology that strengthened and endorsed Turkish identity. It was also tactical because the party aimed to channel the support of the Muslim masses towards itself, and their level of antiCommunist mobilization rose as a result.

The party congress in Adana in February 1969 marked the end of the transformation period for the party, and its name was changed from CKMP to MHP. The congress instituted a hierarchical structure within the party, primarily expanding the powers of Türkeş. The grass-root Turkists of the MHP opposed the Islamisation of the party's rhetoric, and as a result were expelled from the party. The party's strong anti-capitalist and anti-masonic 
stance was also reduced, a tribute to the workings of the forces of the system, which increasingly considered the MHP as a legitimate force because of its stringent anti-Communism. Between 1969 and 1974 the MHP was not an important actor in Turkish parliamentary politics. The party's share of the vote in the elections of 1969 and 1974 were 3 per cent and 3.4 per cent respectively.

The MHP started to build up its support during the government of the Cumhuriyet Halk Partisi (Republican People's Party) in 1974 and was given a great opportunity when the party was invited to join the new Milli Cephe (National Front) government in 1975, with the centre right Adalet Partisi (Justice Party, AP) and the Milliyetçi Selamet Partisi (Nationalist Salvation Party, MSP).$^{18}$ The MHP was invited to join the coalition government on the one hand for its strong anti-Communist position, which was regaining support from the right of the political spectrum parallel to the rise of revolutionary movements. Secondly, the centre right was aware of the need for a coalition of the right-wing forces against the rising CHP that was gaining support from the outcome of the military intervention in Cyprus, conducted under Bülent Ecevit's premiership. ${ }^{19}$

Between 1974 and 1977 the MHP became the party for marginalized middle classes who faced difficulties in adapting to the rise of entrepreneurial capitalism and inflation. Although the MHP almost doubled its support in the 1977 elections, the coalition experience was not as beneficial as its leaders had expected. It had been hoped that this experience would integrate the party into the system as a legitimate actor and widen its basis of support. The party failed to redefine its strategy, and its tactics remained the mobilization of the masses around a primitively defined antiCommunist ideology. The party employed an inflexible attitude towards change, which damaged its electoral prospects. The curtain fell on the MHP in 1980 when the party was closed down and its leaders were banned from indulging in political activity.

If it was the Nouvelle Droite that has become the primary source of French extreme right-wing ideology in France, it is the Aydınlar Ocağı in Turkey that has armed the right in general and the extreme right in particular with a powerful doctrine. The AO was founded in 1970 by a number of respected professors from various disciplines, including economics, engineering and medical science. Its purpose was to unite the 'right' in Turkey, which at the time was disintegrating. This process resulted in the foundation of three different parties, all coming from the DP tradition. As a result the centre right was represented by the AP, the Islamist right by the MSP and the nationalist right by the MHP. The founders of the organization worried that this fragmentation only benefited the left. The primary aim of the AO was to bring the right under one ideological 
umbrella, and strengthen it in its fight against the increasing Communist threat. According to Abdurrahman Dilipak, a well-known Islamist writer, the founders of the think-tank "were under the influence of neither masonic groups as was the AP, nor Islamist groups as was the MSP, nor nationalist groups as was the MHP, but were close to these groupings without, however, representing any of them' ${ }^{20}$ But, according to Tan1l Bora and Kemal Can, given the Turkist-nationalist past of the first chairman, İbrahim Kafesoğlu, and the think-tank ideologue Muharrem Ergin, and the strong anti-Communist element during the foundation of the organization, the $\mathrm{AO}$ set itself the task of establishing a bridge between the AP and the MHP. ${ }^{21}$ The politicization of Islam by the MSP was not supported by the organization, but it rather maintained a secular-conservative stance in line with the Turkish centre right's traditions.

It was this position that has increased the communication between Kemalist military-civilian bureaucracy and the Aydınlar Ocağı, and helped legitimize the organization's ideas. Actually, the rhetoric of the AO has always has always been informed by Kemalist ideology. According to Tanil Bora and Kemal Can, this relationship, as frequently stressed by the left, cannot be dismissed as a purely tactical manoeuvre, intended to hide a different ideology behind Kemalism. ${ }^{22}$ The early republican period under the leadership of Atatürk is interpreted as the glorification of Turkish nationalism. In this respect, Atatürk is considered to be the greatest of all Turkish nationalists. The first phase of the republic deserves utmost respect, because it takes 'national culture' as its basis.

Like the Nouvelle Droite in France, Aydınlar Ocağı is careful to define Turkish nationalism in terms of 'national culture' rather than race. ${ }^{23}$ Political authority could only be legitimate if it is derived from this national culture. Here one can trace the marks of authoritarianism in the AO's ideology. Hence, it may be argued that an authoritarian regime based on Turkish national culture is a legitimate form of government. Following the 1980 coup, the AO's glorification of the Turkish state and national culture gave the organization a special position in its relations with the military junta. This privileged posture went as far as the active participation of the $\mathrm{AO}$ in preparing the 1982 constitution, from which other civilian organizations were normally banned.

In their proposed Milli Mutabakatlar (National Consensus) programme, the organization created a new doctrine, Türk-İslam sentezi (TurkishIslamic synthesis), which was well tailored to fit the aims of the military junta to create a harmonious society. Turkish-Islamic synthesis successfully combined republicanism with conservatism (which is shaped by moderate Islamic motives). This strategy had twofold advantages for the AO. On the one hand, through its support for the Kemalist reforms and republicanism, 
the organization was respected at the state level. On the other hand, its new doctrine coincided with that of the military junta, which was trying to cement the nation with Islam.

Turkish-Islamic synthesis was first mentioned and named by Professor Ibrahim Kafesoğlu, the first chairman of the Aydınlar Ocağı, in the 1970s. In the 1970s Kafesoglu, not departing remarkably from his earlier writings which were underpinned by grass-root Turkist ideas and a version of romantic Turkish nationalism, started to view Islam as an important part of Turkish culture. However, Islam is interpreted only as a part of Turkey's glorious history, and it serves the highest ideal: to achieve Turkish domination over the world. Hence Islam is one of the components of Turkish culture among many others, and does not have any superiority over the other constituents. The thesis that the Turks always had a monotheistic belief is strongly emphasized and Islam is seen as the last stage in the historical evolution of the Turks in achieving their goal to rule the world. It is for this reason that many Turks willingly accepted Islam as their religion. It is also argued that it was the Turks who saved Islam from defeat through accepting its principles and who reunited the Islamic peoples of the world. The Turks have also revised Islam realistically and rationally and through their secular ethos, deeply rooted in their history, introduced the separation of state and religion, the first and only Islamic society to do so. Hence it was the secular tradition and the national culture of the Turks that glorified Islam and established a civilization that was comparable to the earlier civilizations of the followers of the prophet Mohammed. Rather than Turks adapting to the principles of Islam, it was Islam that was tailored to the national culture of the Turks.

The synthesis manifested by Aydınlar Ocağı not only combines Turkish and Islamic values but also incorporates western elements into its ideology. Advancement in science, technology and economics, and support for the military and political doctrines of the West are all parts of the synthesis. For Abdurrahman Dilipak, the Turkish-Islamic synthesis would be better described as 'Kemalist-Islamic'. ${ }^{24}$ It is for this reason that the MHP easily internalized the ideology of the AO. The three elements of MHP ideology are ranked, in descending order, as Turkish, Islamic and western. The critical significance of the AO's amalgamation, however, does not derive from its capacity to combine these three elements successfully, but lies in the authoritarian framework which it proposes. The Aydınlar Ocağı fostered the authoritarian elements in the MHP programme, and through its good relations with the civilian-military bureaucracy gave the MHP a legitimate and sometimes respected place in the state apparatus. The MHP did after all use its status as a party to advance the Turkish nationalist ideal, and so it deserved a priviliged position vis-à-vis other right-wing parties. ${ }^{25}$ 
In economic matters, the think-tank favoured the preservation of the status quo, strongly advocated private entrepreneurship and always claimed to support private property. Given its intermediary role between the centre right and the MHP, it never voiced anti-capitalist sentiments, and was in fact closely linked with big capital. The MHP, primarily supported by deprived peasants, small entrepreneurs and small craftsmen could not adopt the economic programme of the $\mathrm{AO}$. The party, rather, stuck to an old-fashioned extreme right-wing economic programme, essentially corporatist. In France, after internalizing the respectable economic programme of the Nouvelle Droite, the FN nearly doubled its support at the polls. This might explain why the MHP could not achieve a similar electoral turnout to that of the FN in France.

The influence of the Aydınlar Ocağ 1 on Turkish politics was thus extensive, despite its being a small organization with only around 130 members. The organization always kept its elite nature and successfully established a reputation for taking in the entire right of the political spectrum, without associating itself with any of the parties. For this reason, the contribution of the organization to the MHP programme was limited. However, in the final analysis it was the MHP which most benefited from the 'nationalization of politics' in Turkey, the outcome of the endless efforts on the part of the AO.

The attempt by the MHP leaders to mobilize the masses through violent anti-Communist ideas has caused some writers to make a fundamental error in interpreting the position of the party in Turkish politics. The MHP was said to be only a reactionary single-issue movement, its electoral prospects heavily related to its ability to exploit the issue of anti-Communist sentiments among the population..$^{26}$ However, following the collapse of the Communist bloc in 1989, the continuing appearance of the party at the polls has proven that while the Communist ideology was in decline in the world and while its fortresses were falling apart one after the other, the MHP was still a dynamic and a promising force in Turkish politics. Between the years 1989 and 1995 the party nearly doubled its electoral turnout and became a political force ready to pass the ten per cent national threshold for parliamentary representation. As Wolfreys has shown for the FN in France, the MHP in Turkey 'Motivated by the pragmatic demands of satisfying a heterogeneous membership and the opportunist desire to benefit from events ... proved itself capable of adapting its message to a given situation. ${ }^{27}$

Since the early 1990s it has exploited the Kurdistan Worker's Party ${ }^{28}$ (PKK) issue, claiming that there is a conspiracy of foreign enemies to use the PKK to destroy the unity of the Turkish state. During a period in which the funerals of soldiers who were killed in clashes with terrorists often 
turned into political rallies against the PKK and separatism, the message of the party was readily accepted by an increasing proportion of the electorate. The party in fact, through mobilizing anti-PKK sentiments among the population, was not deviating from its original path, to declare war against a fictitious or a real enemy. Therefore, switching from an anti-Communist stance to an anti-PKK one only shows that the party as an institution is capable of adapting to changing conditions.

Since the 1967 congress, the centrepiece of the party programme has been based on the Dokuz Işı Doktrini (DID), 'the path of development and glorification' written by Alparslan Türkeş. ${ }^{29}$ In the 1993 party programme, the DID is introduced to the reader as a doctrine that eliminates all liberalcapitalism, Communism, westernism, and imitationism as systems that are against the history and traditions of the Turks. Therefore, it is absolutely essential to draw a purely national path that would glorify the history, traditions and the roots of the Turkish nation. Against possible criticisms that would label the DID Fascist, Türkeş underlines the differences between national-socialism and his principles: 'National-socialism is based on capitalism, (anthropological ) racism, created in laboratories, and antidemocratic ideas. However, the followers of the DID believe in Turkish communitarianism, a social-pyschologically defined (moral) respect for ancestoral traditions (lineageism), and a true democratic system. ${ }^{30}$ The MHP believes that this doctrine is the exclusive guide for a people loyal to Turkish nationalism. The DID's nine principles are: nationalism, idealism, moralism, communitarianism, positivism, ruralism, libertarianism and character-building, modernization and populism, and industrialism.

The first four principles show the corporatist nature of the programme. It is clearly stated that the MHP movement is a reaction to individualism, competition and a society based on the political economic struggles between the classes. Turkish society is viewed as an organic whole and the programme aims to abolish class conflict and to create a harmonious society. As with corporatism, Turkish society is seen as a body and the individuals as the cells composing it. The criticisms of both egalitarianism and capitalist economic ideas, and the extreme glorification of a paternalist state idea, strengthen the corporatist character of the MHP programme.

The party views democracy as a virtuous regime and believes it to be superior to Communism, Fascism and Nazism. Turkish nationalists claim to be democrats who have adopted democratic rules and principles. However, the latest developments in the congress (explored in detail above), and the corporatist and Fascistic elements in the party programme raise doubts as to the position of the MHP vis-à-vis democracy. The MHP, like many West European extreme right-wing parties, has successfully clothed a Fascist ideology in conservative language. Therefore, it is not a mistake to call the 
MHP programme 'an iron hand in a velvet glove'. ${ }^{31}$

Departing from neo-liberal extreme right-wing parties in Europe, the MHP does not accept economic liberalism, but continues to favour traditional corporatist policies. ${ }^{32}$ For instance, the FN in France considers capitalism as "the highest form of democracy, making individuals responsible for the setting up and running of businesses and then subjecting their decisions to the will of the people, via the market' ${ }^{33}$ However, the MHP discards capitalism on the grounds that it is individualist, fosters cosmopolitanism and because it strongly rejects interventionism. The rejection of capitalism is based on the phrase 'big fish eat small fish', and the small fish is Turkey while the big industrialists and western capital are the big fish. It is capitalism, under the mask of democracy, that is responsible for the poverty and backwardness of Turkish society. ${ }^{34}$ Marxism on the other hand is rejected because of its class-based materialistic ideology.

The economic programme of the MHP is based on import substitution, which of course conflicts with the direction of world trade after the GATT agreement. The party favours import substitution in fundamental industrial sectors, while it also encourages an export-oriented strategy in the sectors which have a potential for competition in the world markets. With the application of this policy, the national resources of Turkey will not, it is claimed, be wasted anymore. The MHP puts itself forward as defender of the farmers. The agricultural sector will be modernized, living conditions and educational opportunities for farmers' families will be improved, and a state subsidy will continue, though kept at a reasonable level. The party aims to build 'agriculture cities' which would be surrounded by light industrial plants. ${ }^{35}$ This would also help to solve the increasing unemployment problem in Turkey.

The MHP sees unemployment as the most important problem facing Turkey. The party, unlike its counterparts, is not against birth control, ${ }^{36}$ and argues that unemployment can only be defeated through investment, and the creation of jobs to match the increase in the population. ${ }^{37} \mathrm{~A}$ change in the national education priorities to widen technical and professional education would also result in reducing unemployment rates. Apart from highly qualified students, who would attend universities, the rest would be channelled into vocational education. Hence, in a short period of time, the active population between the ages of 15 and 16 would be employed in various fields of the economy.

The MHP favours tax reductions for the lower and lower-middle classes. For instance, the minimum wage is to be allowed against tax. Taxes will be collected according to the capacity of citizens and the citizens will be educated so that tax paying becomes a national duty and a matter of social 
responsibility. Unemployment insurance will be introduced in Turkey, as it is in many advanced and prosperous societies in the West. Trade unions are to be accepted as legitimate actors in politics and free trade unionism is advocated. In every sector, strong trade unions will be encouraged and the rights of the workers will be guaranteed vis-à-vis the employers. Two major reservations remain on the trade unions: Firstly, the trade unions must not become centres for class struggle, ${ }^{38}$ and secondly, the trade unions' power must not be abused by its leaders for other ends.

It is clear that during the period of an expanding universal market, the MHP's traditionally defined right-wing nationalism and authoritarianism does not offer much to the average Turkish citizen, whose economic ideas are shaped increasingly by the globalization of world trade. The MHP's manifest desire, for example, to institute state intervention in the economy, contrasts with the ideas of many Turks, who favour large-scale privatization and the minimization of state intervention. Rejecting full membership of the EU, based on cultural aspects and an anti-imperialist ideology, the MHP also disregards the opinion of nearly two-thirds of the Turkish population, which believes that membership of the EU would be to the benefit of Turkey. The greatest contradiction of the MHP programme lies in its recognition of individual and democratic freedoms. This contradiction is especially apparent in the party's attitude towards gender-related issues.

The family is seen as the core social unit of Turkish society. The MHP considers a strong family structure as guaranteeing the preservation of Turkish culture. Mothers, as devoted housewives, will be educated in order to create traditional close-knit families. Feminism, considered a threat to the family and its social functions, is firmly rejected. However, the party claims to support women's rights. The protection of women is necessary; they will be respected equally with men. Abortion is strictly rejected on the grounds that it is the result of ineffective family planning schemes. Therefore, diverging from many European extreme right-wing parties, the MHP in Turkey is not against contraception. The MHP, opposing artificial insemination, openly states how it regards individual freedoms:

It is not enough if husband and wife decide to have babies through artificial insemination. The family is a member of society and it cannot be excluded from it. Against the common morality of the society and its traditions we reject unlimited individual freedoms. ${ }^{39}$

Hence, the party is in contradiction with its own principles stated under the 'The Protection of Basic Rights and Freedoms' section of the programme. ${ }^{40}$

The MHP today is trapped in a deadlock in redefining its ideology as a consequence of the rise of political Islam in Turkey. A part of the Idealist cadres following the 1980 military intervention were influenced by the 
winds of political Islam and consequently founded their splinter party, the Büyük Birlik Partisi (Grand Unity Party, BBP). ${ }^{41}$ The splinter party's place in Turkish politics could be defined as falling somewhere between the Islamist RP and the nationalist MHP. The rivalries between the Islamists and the Turkists are in fact part of MHP history. The difficult combination of nationalism (the idea of belonging to a nation) and Islam as a world religion (belonging to a larger Muslim family) has always been problematic for the party. The MHP as a body embraced a wide spectrum of ideas, very often in contradiction with each other, such as paganism, Kemalism and strong Islamic beliefs. However, the party was able to keep its unity for nearly four decades and has always been a significant actor in Turkish politics, through legal or illegal means. The MHP's success is underpinned by two factors. On the one hand, the MHP accepts all of Turkey's past. All pre-Islamic, Ottoman and Republican periods are considered to be parts of Turkey's glorious heritage. ${ }^{42} \mathrm{On}$ the other hand, the leadership principle, supported by a hierarchical structure, has kept different factions within the party together.

To the small merchant, small artisan, farmer and unemployed worker who have suffered from an inflationary economy for decades, the MHP offers an identity, a past to be proud of and a place in the hierarchy, granting the weak the safety of authority while satisfying their need to dominate. The observations of one MHP sympathizer, Osman Ateş, during Türkeş's visit to their town are as follows: '[Türkeş] is a very serious man. He is disciplined and authoritarian, therefore, I liked him ... he also talks about our history and traditions, underlines the importance of morality...I have decided to support such a man under any circumstances. ${ }^{, 43}$ As a result of his observations the sympathizer accepts an active role in the setting up of the MHP party organization in Gümüşhane. Hence it is the traditional men in an identity crisis, intensified as a result of the modernization process in Turkey, the secularization of lifestyles and decline in traditional values, who support the party and in it find themselves a new identity. Mustafa Calık's words, who has been a member of the Idealist community in the past, shows us what the MHP offers to the ordinary man challenged by modernization:

I am not no longer given either the false security or the untrustworthy power of an organized society [the Idealists]. For this reason, I do not carry with me the tribal responsibility derived from 'belonging', that is restrictive, unreasonable and vain. ${ }^{44}$

It is, therefore, the offer of security by the MHP, that has attracted many people to vote for the party. With reference to the idea of a state that protects its citizens as a father protects children, tax reductions for lower and middle income groups, exploitation of the fear of Communism that is common for the ordinary man in small provinces, and a strong emphasis on conservative 
moral and family values, the MHP's ideas were all tailored to fit the ideas of the marginalized blue-collar workers, small shopkeepers and artisans, unemployed and small farmers. ${ }^{45}$ However, today the challenge of the RP and the BBP threatens the traditional electoral basis of the MHP. The Aydınlar Ocağı is no longer an active organization that may help the MHP to redefine its ideology and become a centre for attraction for the deprived citizens. The MHP today fights a war on two fronts; one against the centre parties, which are increasingly incorporating nationalist rhetoric into their ideology, and the other against the Islamists represented by the RP and the BBP.

Today, Turkey is going through a period of vehement political chaos. The so-called 'Refahyol' coalition government between the RP and the Doğru Yol Partisi (True Path Party, DYP), has intensified the polarization between the secular republicans and the advocates of shariah rule. The polarization of the system has not yet reached the level of civil war; however, the unrest of the military gives the early signals of an antidemocratic take-over; a military coup. What is more worrying for Turkish democracy is the attitude of some sections of the media which advocate (reading between the lines) military intervention and anti-democratic measures in order to preserve the secular republic. During such a chaotic period it is probable that the Fascist and authoritarian ideas of the MHP may find fertile ground. However, the MHP, like the centre right Anavatan Partisi ${ }^{46}$ (Motherland Party, ANAP), seems to be trapped between Islamist and pro-republican ideas, and hence may split into a number of parties. The most popular slogan of MHP supporters in the 1990s shows this dilemma. Although claiming to give priority to Turkist ideas over Islamic ones, the slogan of the party has an Islamic undertone rather than a Turkist one. The supporters shout in MHP meetings: 'Ya Allah, Bismillah, Allahü Ekber' [Oh God, in the name of God the compassionate the merciful, God is the greatest].

The future prospects of the party are directly linked to the developments that will take place during the suspension of congress. If MHP successfully transforms its ideology towards a more centre-oriented one, as the Movimento Italiano Sociale-Destra Nazionale (Italian Social MovementNational Right, MSI-DN) ${ }^{47}$ in Italy has done, the party will have the chance to gain a more respectable and significant place in Turkish politics. Otherwise, it is most likely that the heritage of the MHP will be divided among a number of parties, including the Islamist $\mathrm{RP}$ and the BBP as well as the centre-right parties. Today, the MHP no longer has a monopoly of Fascistic elements and authoritarianism. 


\section{NOTES}

1. According to Alparslan Türkeş, the ideal is to construct a Turkish nation that is the most advanced, civilized, and powerful entity of the world. People who follow this ideal, are the idealists. Idealists must be ready to sacrifice themselves in serving the state and the nation. See, Türkeş, Alparslan, Milliyetçilik (Istanbul: Hamle Basın-Yayın, 1996), p.16.

2. The splinter party is Büyük Birlik Partisi (Grand Unity Party, BBP) led by Muhsin Yazıcıoğlu a former NAP member. The party emphasizes the Islamic roots of Turkish culture and advocates a Turkist-Islamist programme. For Yazıcıoğlu and his friends Islam occupies a central role in Turkish nationalism, while for the NAP followers Islam is only one of the ingredients of Turkish nationalism among others.

3. Turkish word for 'Führer'.

4. For the pre-1980 MHP atrocities see the confessions of two Idealists, Omer Tanlak and Ali Yurtaslan. Tanlak, Omer, Itiraf: Eski Ülkücü MHP'yi Anlatlyor (Istanbul: Kaynak Yayınları, Second Edition, 1996). Yurtaslan, Ali, Itiraflar: MHP Merkezindeki Adam Abdullah Catl' 'yl Anlattyor (Istanbul: Kaynak Yayınları, Second Edition, 1997).

5. Türkeş, Alparslan, Milliyetçilik, p.16.

6. The MHP administration denied such an illegal link and argued that such a person could not be a member of their community. However, his funeral was dominated by the Idealists, and he was claimed as a martyr who fought for the cause of Turkish nationalism.

7. The relationship between Abdullah Chatli and the MHP is explained in the confessions of Ali Yurtaslan. See, Yurtaslan, Ali, Itiraflar: MHP Merkezindeki Adam Abdullah Çatli'yi Anlattyor.

8. Büyükbaş, Adnan, Ülkücüye Mektuplar (Istanbul: Hamle Basin-Yayin, 1995). I have rephrased the words of Adnan Buyukbaș, since a direct translation from Turkish to English turns out to be meaningless.

9. At the time the party used a different name, Milliyetçi Çalışma Partisi (Nationalist Work Party, MÇP), for the previous one was still banned from politics.

10. In order to pass the national threshold of ten per cent, an electoral pact between RP, MHP and a minor third party was formed before the 1991 general elections. Therefore, the results represents neither the electoral strength of the RP nor the MHP alone.

11. Coşkun, Bekir, Hürriyet, 8 April 1997, p.3.

12. DP government was ended by the 1960 military intervention and three ministers, including the prime minister, Adnan Menderes, were executed by the military junta. Alparslan Türkeş, as a colonel, was active during the early phases of the coup d'etat.

13. The last one, RP, is at least considered to be an enemy by the top administration of the party. In his last interview before his death, to which the media gave extensive coverage, Alparslan Türkeş pointed at the threat of Islamic Fundamentalism represented by the RP.

14. Alparslan Türkes, Milliyetçilik, p.17.

15. Milliyetçi Hareket Partisi Programı (Ankara, 24 Ocak 1993), pp.37-8.

16. This organization was the continuation of Türkçüler Derneği (Turkists Club), which was founded in 1963 by grassroot racists, such as Nihal Atsız and İsmet Tümtürk.

17. Tanıl Bora and Kemal Can, Devlet, Ocak, Dergah: 12 Eylül'den 1990'lara Ülkücü Hareket (Istanbul: İletişim Yayınları, Third Edition, 1994), p.54.

18. Today's Islamist RP is the continuation of the MSP.

19. Bülent Ecevit at the time was the leader of CHP.

20. Dilipak, Abdurrahman, Türkiye Nereye Gidiyor? (Istanbul: Risale Yayınlan1, 1988).

21. Bora, Tanil and Kemal Can, Devlet, Ocak, Dergah, pp.152-3.

22. Ibid., pp.155.

23. For a summary of Nouvelle Droite's ideas on the matter, see Jim Wolfreys, 'The Programme of the National Front: An Iron Hand in a Velvet Glove', Parliamentary Affairs, Vol. 46, No. 3 (July 1993).

24. Dilipak, Abdurrahman, Türkiye Nereye Gidiyor?

25. Turkish-Islamic synthesis section is primarily adapted from, Tanıl Bora and Kemal Can, Devlet, Ocak, Dergah, pp.160-77.

26. Ömer Laçiner, 'Foreword', Tanıl Bora and Kemal Can, Devlet, Ocak, Dergah, p.10. The 
interviews conducted with 870 MHP voters as to how they had become supporters of the movement in the late 1970 s reveals that only 30 per cent of them voted for the party with pure anti-Communist motives. Here one needs to stress that during this period antiCommunist sentiments were at their peak in Turkey. For the results of the interviews see Mustafa Calık, MHP Hareketi, -kaynakları ve gelişimi-, 1965-1980 (Ankara: Cedit Neşriyat, 1995), pp.149-61.

27. Jim Wolfreys, 'The Programme of the National Front: An Iron Hand in a Velvet Glove'.

28. An outlawed Kurdish terrorist organization which fights for a free Kurdistan, including lands from Turkey, Iraq, Iran and Syria.

29. Milliyetçi Hareket Partisi Programı (Ankara, 24 Ocak 1993), pp.16-8.

30. Alparslan Türkeş, Milliyetçilik, p.19.

31. The FN programme is referred to as 'an iron hand in a velvet glove' by the organization itself. See E. Plenel and A. Rollat, La République Menacée (Paris, 1992), p.248 cited in Wolfreys, 'The Programme of the National Front'.

32. For instance, both the FN in France, and the Freiheitliche Partei Österreich (Freedom Party of Austria, FPO), have adopted economic liberalism in their programmes. For the FN, see Wolfreys, 'The Programme of the National Front'. For the FPO, see FPO, Programm für Wien 1991(Vienna: Landesgruppe Wien, 1991).

33. Wolfreys, 'The Programme of the National Front'.

34. Bizim Ocak, May 1990, p.3, cited in Bora and Can, Devlet, Ocak, Dergah, p.349.

35. For a more detailed analysis of the 'agriculture cities', see Tahsin, Yahyaoğlu, Tarim Kentleri-Milliyetçi Toplumcu Düzen (Dokuz Işılk Üzerine Incelemeler) (Istanbul: Milli Ülkü Yayınevi, 1975).

36. See below on family and moral values.

37. The average increase in the population in Turkey is 2.4 per cent per year.

38. The MHP is against Marxist or Socialist trade unions.

39. Milliyetçi Hareket Partisi Programı (Ankara, 24 Ocak 1993), p.8.

40. Ibid., pp.12-13.

41. For a detailed analysis of how the 1980 military coup affected the Idealist cadres see, Bora and Can, Devlet, Ocak, Dergah, pp.101-47.

42. For a detailed analysis of the MHP's interpretation of Turkish history, see Türkeş, Milliyetçilik, pp.29-40.

43. Mustafa Çalık, MHP Hareketi, -kaynakları ve gelişimi-, 1965-1980 (Ankara: Cedit Neşriyat, 1995), pp.133-4.

44. Ibid,, backcover.

45. Türkiye Sosyal Ekonomik Siyasal Araştırmalar Vakfi (TÜSES), Türkiye 'de Siyasi Partilerin Seçmenleri ve Sosyal Demokrasinin Toplumsal Tabanı (Ankara: Cem Yayınevi, 1995), pp.47-8.

46. For instance, when women's associations marched against sharia rule, the leader of ANAP, Mesut Yilmaz, stated that they do not support a march against sharia rule, because it can be interpreted as a march against religion.

47. The party changed its name to Alleanza Nazionale (National Alliance, AN). 